\title{
STRATEGI PEMASARAN BERBASIS ONLINE PADA PRODUK BADAN USAHA MILIK DESA (BUMDES) "SUKSES BERSAMA" DESA SUGIHWARAS KABUPATEN SIDOARJO
}

\author{
Riris Eka Widayanti ${ }^{1}$ \& Renny Oktafia ${ }^{2}$ \\ ${ }^{1 \& 2}$ Program Studi Perbankan Syariah, Pascasarjana Universitas Muhammadiyah Sidoarjo \\ Email : ririswidayanti@gmail.com,renny.oktafia@umsida.ac.id
}

\begin{abstract}
ABSTRAK
Munculnya pandemi covid-19 harus disikapi oleh para pelaku usaha dengan penerapan langkahlangkah strategis untuk kelangsungan bisnisnya. Bisnis online pada situasi saat ini merupakan sebuah peluang atau kesempatan yang sangat menjanjikan dan terlebih juga menguntungkan untuk dikembangkan. Bisnis online juga tidak menutup kemungkinan adanya kendala, seperti persaingan yang ketat karena banyaknya kompetitor yang berdampak pada sempitnya cakupan pemasaran produk. Desa Sugihwaras merupakan salah satu desa yang sudah menjalankan roda perekonomian yaitu melalui pembentukan BUMDes. Salah satu bentuk inovasi yang sedang dikembangkan dan berjalan oleh BUMDes Sukses Bersama yaitu melakukan pemasaran produk BUMDes berbasis online melalui aplikasi market place yang dimiliki yaitu Elektronik Bumdes Sugihwaras (E-Bes). Tetapi sampai sekarang penggunaannya belum maksimal, sebab banyak masyarakat Desa Sugihwaras belum mengetahui adanya aplikasi tersebut, ketertarikannya hanya $40 \%$ saja. Tujuan dari penelitian ini untuk mengetahui bagaimana strategi pemasaran dan dampaknya pada perekonomian desa.
\end{abstract}

Kata kunci : Strategi Pemasaran, Bisnis Online, BUMDes Sugihwaras.

\begin{abstract}
The emergence of the Covid-19 pandemic must be addressed by business actors by implementing strategic steps for the continuity of their business. Online business in the current situation is a very promising and even more profitable opportunity to develop. Online business also does not rule out the possibility of obstacles, such as intense competition because of the large number of competitors which have an impact on the narrow scope of product marketing. Sugihwaras Village is one of the villages that has run the economy through the formation of BUMDes. One form of innovation that is being developed and running by BUMDes Sukses Bersama is marketing BUMDes products based online through its market place application, namely Sugihwaras Bumdes Electronics (E-Bes). But until now its use has not been maximized, because many people in Sugihwaras Village do not know about this application, only $40 \%$ of interest. The purpose of this research is to find out how the marketing strategy and its impact on the village economy.
\end{abstract}

Keywords : Marketing Strategy, Online Business, BUMDes Sugihwaras. 


\section{PENDAHULUAN}

Persaingan usaha yang semakin ketat pada ero globalisasi hingga munculnya pandemi covid-19 harus disikapi oleh para pelaku usaha dengan penerapan langkah-langkah strategis untuk kelangsungan bisnisnya. Dampak dari pandemi yang melanda di seluruh dunia mengakibatkan kesulitan perekonomian, sehingga pelaku usaha diharuskan memperbaruhi sistem penjualannya. Salah satu usaha yang dapat mewujudkan sistem ini yaitu dengan pemasaran online dan diharapkan juga bisa memperbaruhi sistem konvensional yang telah ada di masyarakat (Fadly \& Sutama, 2020).

Perkembangan bisnis online telah merambah sejalan dengan perkembangan teknologi, komunikasi, komputer dan juga gawai. Hal ini secara otomatis sangat berdampak terhadap pertumbuhan perekonomian masyarakat. Bisnis online pada situasi saat ini merupakan sebuah peluang atau kesempatan yang sangat menjanjikan dan terlebih juga menguntungkan untuk dikembangkan, adanya perkembangan perangkat komunikasi yang sekarang banyak beredar yakni perangkat smartphone berbasis android yang dengan mudah didapatkan dengan harga yang terjangkau. (Hastriyandi \& Munandar, 2018)

Indonesia juga merupakan negara dengan pengguna teknologi terutama berbasis android terbanyak, sehingga hampir seluruh masing-masing masyarakat telah memiliki ponsel pintar. Hal ini juga dibuktikan dengan bertambahnya data pengguna akses internet di Indonesia pada tahun 2015 2019 sebagai berikut:

Gambar 1. Grafik Pengguna Internet di Indonesia 2015-2019

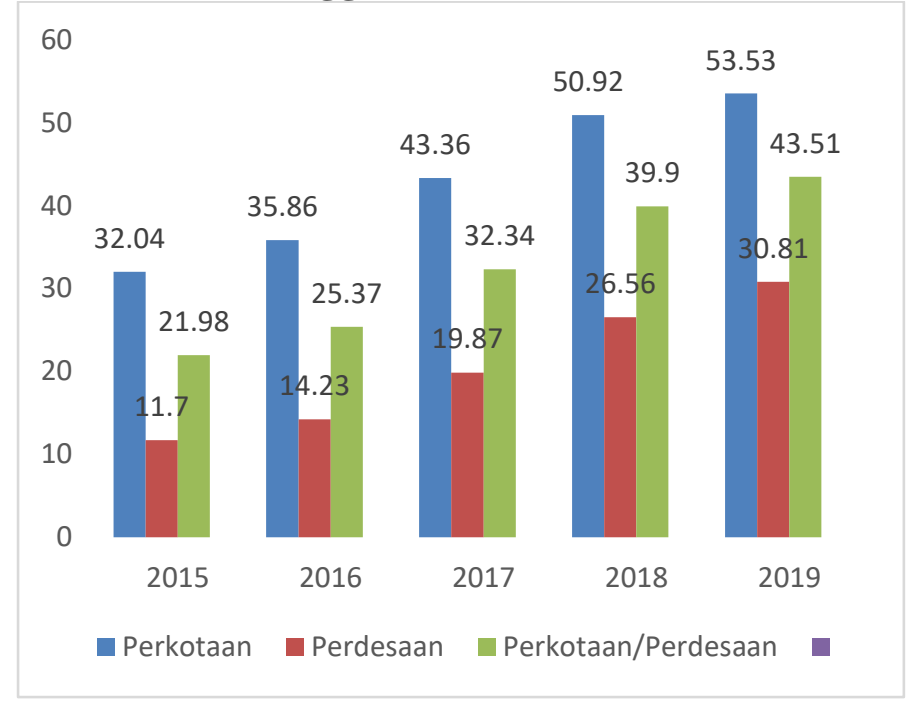

Sumber : Badan Pusat Statistik (2019)

Pada tahun 2015, persentase penduduk yang menyatakan pernah mengakses internet sekitar 21,98 persen dan meningkat menjadi 43,51 persen pada tahun 2019. Peningkatan penggunaan internet ini terjadi baik di daerah perkotaan maupun perdesaan. Di daerah perkotaan, persentase pengguna internet pada tahun 2015 sekitar 32,04 persen dan meningkat menjadi 53,53 persen pada tahun 2019, sedangkan pengguna internet di daerah pedesaan pada tahun 2015 sekitar 11,70 persen dan meningkat menjadi 30,81 persen pada tahun 2019 .

Oleh karena itu, bisnis online dapat juga membuka peluang untuk para 
pelaku usaha dalam pengembangan bisnisnya. Bisnis online juga tidak menutup kemungkinan adanya kendala, seperti persaingan yang ketat karena banyaknya kompetitor yang berdampak pada sempitnya cakupan pemasaran produk. Terdapat beberapa hal agar memperkuat suatu bisnis yaitu dari faktor internal dan eksternalnya. Faktor Internal, atara lain aspek SDM, manajemen, permodalan, jangkauan pasar, dan aspek inovasi produk. Sedangkan faktor eksternal, antara lain aspek regulasi, pengawasan dan aspek infrasruktur (Oktafia, 2017).

Desa Sugihwaras merupakan salah satu desa yang sudah menjalankan roda perekonomian yaitu melalui pembentukan BUMDes dan sudah berjalan hingga saat ini. BUMDes "Sukses Bersama" Desa Sugihwaras sudah melakukan bisnis berupa pembuatan sabun mandi dan sabun cuci dari bahan alami, pembuatan batik Eco Print, serta adanya berbagai pelayanan dan penjualan untuk memudahkan aktivitas masyarakat.

Saat ini penjualan dilakukan dengan dua cara yakni dari mulut ke mulut dan penggunaan aplikasi online yang dimiliki oleh BUMDes, meskipun telah memanfaatkan sistem digital ternyata banyak masyarakat yang belum mengetahui cara penggunaanya atau ada juga yang belum mengetahui adanya aplikasi tersebut. Pemasaran produk yang dilakukan oleh BUMDes masih pada lingkup warga sekitar saja atau bersifat lokal. Pemasaran digital bisa didefinisikan sebagai strategi dalam melakukan pemasaran sebuah produk/jasa menggunakan perangkat elektronik atau berbasis internet dengan beragam taktik atau strategi marketing dan media digital.

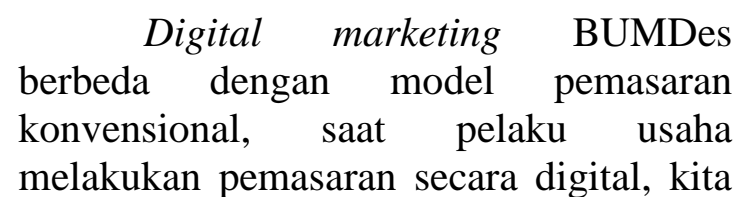

sebagai pemasar dapat berkomunikasi dengan calon konsumen di bidang online secara langsung, sehingga jangkauan pemasaran atau informasi pemasaran yang kita keluarkan dan promosikan dapat dilihat siapa saja yang menjangkau dan berinteraksi terhadap informasi dari produk atau jasa yang kita tawarkan (Hastriyandi \& Munandar, 2018).

Produk atau jasa yang dimiliki BUMDes dapat diinformasikan dengan beragam akses yang dapat dipilih agar calon pembeli di lingkup online dapat melihat penawaran yang disediakan BUMDes, kita dapat menggunakan Website, Blog, Media sosial yang dimana ada calon pembeli atau target pasar dari produk atau jasa yang kita miliki. Dengan penerapan aplikasi virtual shopping ini, tidak perlu kontak fisik antara pembeli dan penjual sebagaimana kondisi yang dibutuhkan saat ini yaitu Less Contact Economy. Nantinya akan dibedakan harga antara agen, reseler dan retail melalui kode yang dimasukkan saat chekout belanja (Sulistiyowati et al, 2021). Pada saat memasarkan produk atau jasa yang dijalankan oleh unit usaha BUMDes, target yang ingin dicapai yakni para pengguna media, maka tim marketing perlu masuk di dunia digital marketing dan membuat penawaran atau pemberian informasi kepada calon konsumen melalui iklan, email, brosur online, dan sebagainya (Fadly \& Sutama, 2020).

\section{TINJAUAN PUSTAKA}

\section{BUMDes (Badan Usaha Milik Desa)}

Dalam UU Nomor 32 tahun 2004 dan PP Nomor 72 tahun 2005 diamanatkan bahwa dalam meningkatkan pendapatan masyarakat dan desa, pemerintah desa dapat mendirikan Badan Usaha Milik Desa (BUMDes) sesuai dengan kebutuhan dan potensi desa. Dalam hal perencanaan dan pembentukannya, BUMDes dibangun atas inisiatif dari masyarakat, serta didasari 
dari prinsip-prinsip kooperatif dan emansipatif. Mengingat bahwa profesionalisme dari pengelolaan BUMDes harus benar-benar didasarkan kesepakatan masyarakat baik dari kepentingan produksi maupun konsumsi harus dilakukan secara profesional.

Seperti yang telah diutarakan diatas bahwa berdirinya Badan Usaha Milik Desa ini karena sudah diamanatkan bahwa dalam meningkatkan pendapatan masyarakat dan desa, pemerintah desa dapat mendirikan badan usaha milik desa. BUMDes sebagai institusi ekonomi rakyat lembaga komersial, pertama-tama berpihak kepada pemenuhan kebutuhan (produktif maupun konsumtif) masyarakat adalah melalui pelayanan distribusi penyediaan barang dan jasa. Hal ini diwujudkan dalam penyediaan kebutuhan masyarakat yang tidak memberatkan, seperti harga lebih murah, mudah didapatkan dan menguntungkan. Dalam hal ini, BUMDes sebagai institusi Komersiil, tetap memperhatikan efisiensi serta efektifitas dalam kegiatan sektor riil dan lembaga keuangan. (Hastriyandi \& Munandar, 2018)

\section{Strategi Pemasaran}

Terdapat beberapa macam pengertian strategi dari para ahli. Menurut (Kotler \& Armstrong, 2011) pemasaran adalah proses dimana perusahaan menciptakan nilai bagi pelanggan dan membangun hubungan yang kuat dengan pelanggan dengan tujuan untuk menangkap nilai dari pelanggan sebagai imbalannya. Fokus perhatian dari pengembangan strategi pemasaran yaitu pada segi kualitas strategi yang nantinya dihasilkan yang bertujuan untuk mendorong kinerja pemasaran. Kualitas strategi pemasaran tercermin dari adanya kualitas perencanaan dan implementasi strategi yang bermutu. (Fadly \& Sutama, 2020)
Strategi pemasaran merupakan rencana yang menjelaskan ekspektasi perusahaan akan dampak dari berbagai aktivitas atau program pemasaran terhadap permintaan produk atau lini produknya di sasaran pasar tertentu. Program pemasaran sendiri meliputi segala tindakan pemasaran yang secara langsung dapat mempengaruhi permintaan terhadap produk, seperti mengubah harga, merancang promosi dan sebagainya (Wibowo et al, 2015). Pada umumnya suatu organisasi bisnis membutuhkan strategi apabila berada dalam beberapa situasi, Pertama sumber daya (manusia, modal, bahan baku, teknologi, waktu, dan lain-lain) yang dimiliki terbatas, Kedua Adanya ketidakpastian mengenai kekuatan bersaing organisasi, dan Ketiga komitmen terhadap sumber daya tidak dapat diubah lagi. (Hastriyandi \& Munandar, 2018)

\section{Langkah-Langkah Perumusan Strategi Pemasaran}

Merumuskan suatu strategi pemasaran berarti melaksanakan prosedur secara sistematis. Terdapat tiga strategi yang menjadi kunci dalam manajemen pemasaran, yaitu: (Wibowo et al, 2015)

a. Strategi Segmentasi Pasar. Yaitu proses dalam membagi pasar ke dalam kelompok para pembeli yang tentunya berbeda-beda berdasarkan perilaku yang membaurkan produk dan pemasaran sendiri, karakteristik dan juga perilaku.

b. Strategi Penentuan Pasar Sasaran. Yaitu tentang pemilihan seberapa. besar atau kecilnya segmen pasar sesuai dengan kemampuan perusahaan untuk memasuki pasar tersebut.

c. Strategi Penentuan Posisi Pasar. Penentuan pasar sasaran adalah sebuah strategi untuk merebut posisi pada benak konsumen. Dengan kata lain strategi ini menyangkut kepercayaan dan keyakinan pelanggan. 


\section{Pemasaran Secara Online}

Strategi pemasaran online atau sering disebut dengan online marketing strategi merupakan segala usaha (bisnis) yang dilakukan untuk melakukan pemasaran suatu produk atau jasa melalui atau menggunakan media online, yaitu internet. Saat ini, pemasaran tidak cukup kalau hanya offline, tapi juga online sehingga konsumen mendapatkan pelayanan dari produk atau jasa yang ditawarkan, jadi sebuah brand tidak hanya mengedepankan digital brandingnya tetapi juga konten yang dibuat (Sulistiyowati et al, 2021). Walaupun mengalami perubahan, pemasaran tidak bisa melepaskan diri dari tiga komponen yang selalu berdampingan, yaitu konsumen, kompetitor dan perusahaan. Ketiga komponen ini yang selalu ada dalam setiap pembahasan tentang pemasaran, Pemasaran secara online terdapat banyak juga manfaatnya, seperti Kenyamanan, Akses dan pilihan macam-macam produk yang lebih besar dan Memberi akses ke banyak informasi. Manfaat dari penjual sendiri yaitu dapat biaya yang lebih murah serta meningkatkan kecepatan pemasaran dan dapat menjadi alat untuk menjalin hubungan dengan pelanggan (Siswanto dan Tito, 2013).

Pemasaran yang dilakukan melalui sistem komputer online interaktif, yang menghubungkan pembeli dan penjual secara elektronik, merupakan bagian terpenting dari e-commerce atau proses perdagangan secara elektronik dengan menggunakan website, blog atau media sosial. Pemasaran meliputi aktivitasaktivitas yang berkaitan dengan penjualan, pengiklanan, promosi serta penentuan harga (Siswanto dan Tito, 2013).

Seorang pemasar wajib untuk mempunyai pengetahuan yang teliti tentang perilaku konsumen agar dapat memberikan definisi pasar yang baik untuk mengikuti arus perubahan yang konsisten dan terus menerus. Perilaku konsumen menggambarkan bagaimana konsumen membuat keputusan- keputusan pembelian dan bagaimana mereka menggunakan dan mengatur pembelian barang atau jasa. (Wandanaya, 2012).

\section{METODE PENELITIAN}

Metode penelitian yang digunakan adalah penelitian deskriptif kualitatif. Metode kualitatif ini sesuai dengan permasalahan yang sedang diteliti yakni Dampak dari pemasaran secara online di BUMDes Sukses Bersama. Pada penelitian kualitatif ini bersifat tidak pasti dan masih terus berkembang (Sugiyono, 2018). Dan penelitian disajikan kedalam bentuk deskriptif yang membahas tentang bagaimana strategi pemasaran yang dilakukan BUMDes Sukses Bersama dalam memasarkan produknya secara online. Sedangkan jenis pendekatan yang digunakan adalah pendekatan yang bertujuan untuk mendalami secara detail bagaimana interaksi sosial, individu, organisasi dan lain-lain terkait dengan permasalahan yang terjadi di tempat (Primasatya, 2014).

Lokasi penelitian dilakukan di BUMDes Sukses Bersama yang bertempat di Jl. H. Nur RT. 011 RW. 003 Candi Sidoarjo pada bulan Desember sampai dengan bulan Maret. Teknik pengumpulan data yang digunakan pada penelitian adalah:

1. Obervasi partisipatif pasif, peneliti melakukan observasi dengan mendatangi kantor BUMDes Sukses Bersama untuk melihat keadaan BUMDEs dan hanya mengamati saja segala aktivitas BUMDes.

2. Wawancara, menggunakan teknik wawancara terstruktur untuk mendapatkan informasi mendalam dari informan.

3. Dokumentasi, data penelitian diperoleh dari wawancara langsung dan via chat. 


\section{HASIL PENELITIAN}

Badan Usaha Milik Desa (BUMDes) "Sukses Bersama" Desa Sugihwaras, Kecamatan Candi, Kabupaten Sidoarjo dibentuk pada tanggal 25 Maret 2019 sesuai dengan Peraturan Desa nomor 07 tahun 2019 tentang pembentukan usaha milik desa (BUMDes)
Sukses Bersama yang mempunyai visi menggerakkan roda ekonomi desa yang bertujuan untuk meciptakan kemandirian desa melalui BUMDes Sukses Bersama. BUMDes Sukses Bersama berada di wilayah RT. 011 RW. 003 Desa Sugihwaras Kecamatan Candi Kabupaten Sidoarjo.

\section{Gambar 2. Struktur Kepengurusan BUMDesa Sukses Bersama}

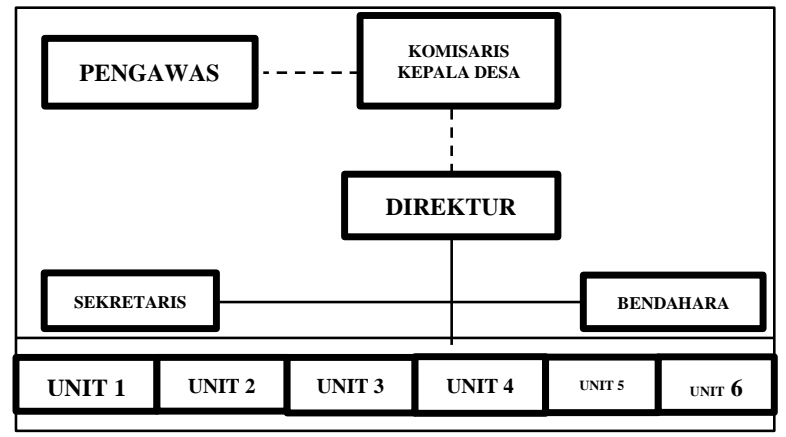

Sumber : Profil Desa (BUMDes) Sukses Bersama (2020)

Terdapat setidaknya enam jenis unit usaha yang di kelola oleh BUMDes Sukses Bersama meliputi: Usaha Simpan Pinjam, UKM (Pembuatan Batik Eco Print), Kios (Kerjasama lumbung pangan, Pengumpulan minyak jelatah, Pembuatan sabun mandi dan sabun cuci), Perikanan (Penyediaan pakan ikan), Aplikasi Pembayaran dan Penjualan E-Bes, Kerjasama dengan Pos FIN dan Pos MLO (Pengiriman Paket).

\section{Strategi Pemasaran Berbasis Online pada Produk Badan Usaha Milik Desa (BUMDesa) Sukses Bersama, Desa Sugihwaras}

Langkah-Langkah Perumusan Strategi Pemasaran pada Produk Badan Usaha Milik Desa (BUMDesa) Sukses Bersama :

\section{Strategi Segmentasi Pasar}

Penentuan segmentasi pasar BUMDes Sukses Bersama dilakukan agar bisnis menjadi tepat sasaran yang variabelnya berupa :

1. Segmentasi pasar untuk pasar konsumen yang meliputi: 1) Usia dan
Pendapatan, yaitu berkisar $<20$ tahun secara umum sudah mempunyai penghasilan dan diharapkan bisa bertransaksi di BUMDes. 2) Pekerjaan, diharapkan tidak hanya kalangan yang mempunyai usaha saja yang bertransaksi tetapi pekerja kantor, TNI dan sebagainya bisa ikut andil dalam mempercayai BUMDes. 3) Perilaku dari konsumen itu sendiri, seperti tanggap terhadap produk yang ditawarkan atau diluncurkan BUMDes Sukses Bersama.

2. Segmentasi pasar untuk pasar industri yang meliputi: 1) Jenis Industri, yang disesuaikan dengan program yang ada di BUMDes Sukses Bersama seperti pengusaha yang mempunyai toko kelontong sehingga BUMDes dapat menyuplai kebutuhan yang ada di toko tersebut. 2) Lokasi Usaha, berada di desa sugihwaras dan diluar sehingga dapat memperdayakan warga disekitar dan dapat memperkenalkan BUMDes Sukses Bersama hingga ke berbagai macam daerah. 
Sesuai dengan hasil wawancara secara online dengan Ibu Lailul Siti Romlah selaku Ketua BUMDes Sukses Bersama bahwa: "Untuk penentuan segmen pasar yang dituju oleh BUMDes, kami harus menyesuaikan dengan program yang dijalankan seperti menjalin kerjasama dengan UKM yang ada di desa sugihwaras untuk menjual produknya melalui BUMDes".

\section{Strategi Penentuan Pasar Sasaran}

Setelah BUMDes berhasil mengelompokkan pasar atau masyarakat berdasarkan karakteristik yang sama maka langkah selanjutnya adalah menentukan segmen pasar mana yang akan dimasuki. Pasar yang akan dimasuki yang disebut sebagai pasar sasaran. Seperti BUMDes Sukses Bersama yang mengajak warga desa Sugihwaras untuk bekerja sama dalam membuat produk. Strategi pemilihan pasar sasaran yang dilakukan BUMDes Sukses Bersama diantaranya adalah :

1. Pasar tidak dibeda-bedakan. Berdasarkan strategi ini BUMDes akan memproduksi satu produk untuk semua konsumen dengan kegiatan yang sama. Seperti BUMDes Sukses Bersama akan menjalankan jasa simpan pinjam dengan menawarkan satu kredit (pinjaman) yaitu kredit usaha dengan jangka waktu 1 tahun untuk setiap konsumen.

2. Pasar dibeda-bedakan. Berdasarkan strategi ini BUMDes Sukses Bersama memproduksi berbagai produk dan ditujukan kepada kelompok konsumen (segmen) yang berbeda dengan program pemasaran yang berbeda pula untuk setiap segmen. Seperti, BUMDes Sukses Bersama membuka usaha grosir barang dagangan selain melayani kebutuhan pedagang kecil misalnya juga melayani konsumen langsung.
3. Strategi penentuan posisi pasar. Tujuan memposisikan produk adalah untuk mempermudah konsumen mengenali produk perusahaan dengan memposisikan produk di pasar. Cara yang dapat digunakan untuk memposisikan produk BUMDes Sukses Bersama secara efektif di pasar adalah:

a. Manfaat, seperti produk abon lele yang diproduksi BUMDes Sukses Bersama dapat menjadi lauk alternatif di rumah.

b. Posisi melawan pesaing, Seperti produk sabun cuci piring dengan bahan alami milik BUMDes saat mempromosikan dibandingkan dengan sabun dengan merek terkenal lainnya.

Produk-produk BUMDes selain dipasarkan secara offline, salah satu bentuk inovasi yang sedang dikembangkan dan berjalan oleh BUMDes Sukses Bersama yaitu melakukan pemasaran produk BUMDes berbasis online melalui aplikasi market place yang dimiliki yaitu Elektronik BUMDes Sugihwaras $(E-B e s)$ yang telah dilakukan sejak awal tahun 2020 lalu. Pencapaian ini membawa BUMDes Sukses Bersama meraih penghargaan sebagai pemenang katagori BUMDes Digital yang diberikan oleh Perserikatan BUMDes Indonesia tahun 2020 dan BUMDES AWARD 2020 oleh PKKPBI ITS (Pamong, 2020). Penjual dalam aplikasi ini hanya bisa dilakukan oleh warga asli Desa Sugihwaras dengan sistem penyaringan yang ketat dari BUMDes Sukses Bersama. Cara mendaftarnya pun sangat mudah yaitu pertama download aplikasi E-Bes terlebih dahulu di playstore, selanjutnya bisa langsung melakukan pendaftaran sebagai penjual.

Setelah melakukan langkahlangkah dalam menyusun strategi pemasaran, BUMDes Sukses Bersama 
juga melakukan strategi pemasaran secara online, meliputi:

\section{Aplikasi Market Place E-Bes Desa Sugihwaras.}

Berdasarkan observasi yang dilakukan di BUMDes Sukses Bersama pada Desember hingga Maret 2021. Aplikasi tersebut berisi berbagai macam jenis produk: a. Makanan dan Minuman khas yang diolah langsung oleh warga desa Sugihwaras, seperti Kue Semprong dan Wedang Uwuh. b. Hingga kerajinan Tas dari rotan dan sebagainya.

Selain menjajakan produk desa, EBes juga digunakan sebagai tempat transaksi jual beli token listrik, pulsa dan paket data, bayar pajak PBB, bayar BPJS dan transaksi online lainnya. Jika ingin warga desa ingin memasukkan produknya di E-Bes, maka wajib menghubungi admin atau petugas BUMDes Sukses Bersama serta menunjukkan deskripsi produk, harga dan lain-lain.

Aplikasi ini dapat digunakan oleh seluruh warga Desa Sugihwaras dalam menjual hasil produknya kepada konsumen secara luas. Tujuan dari adanya aplikasi E-Bes ini tentu saja sebagai sarana fasilitas bagi wirausaha di Desa Sugihwaras dalam memasarkan segala jenis produk dan usaha kepada calon konsumen potensial secara online. Dibalik genggaman smartphone terdapat peluang pengembangan pasar yang besar bagi pelaku UKM (Pradiani, 2017).

Adanya aplikasi market place EBes menjadi kekuatan tersendiri BUMDes Sukses Bersama dalam pemasaran produk yang dihasilkan, selain menjangkau pasar yang tak terbatas, dengan menggunakan aplikasi ini akan menghemat waktu bagi penggunanya baik sebagai penjual ataupun sebagai pembeli.

\section{Gambar 3. Pertumbuhan Transaksi Pembayaran Pada Aplikasi e-Bes (\%)}

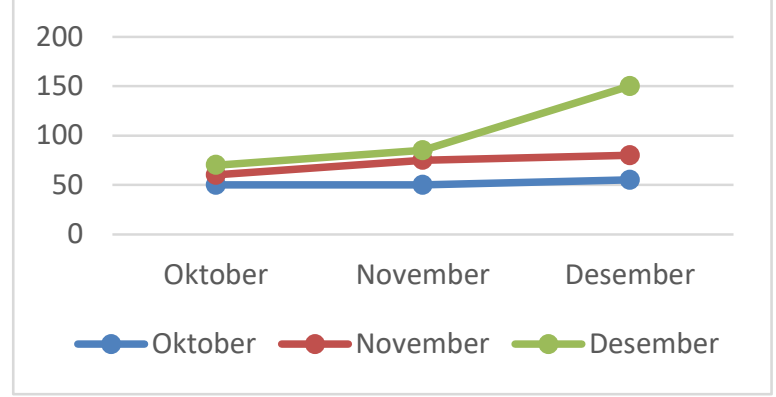

Sumber : Data Olahan (2020)

Dari hasil observasi yang harapan, antusiasme masyarakat yang dilakukan peneliti, transaksi pembayaran PPOB seperti pajak kendaraan, PBB, listrik, cicilan, dan lain-lain di aplikasi $E$ Bes terus meningkat sejak dirilisnya aplikasi tersebut hingga saat ini. Meskipun peningkatannya belum begitu signifikan seperti yang diharapkan. Hal ini juga berlaku pada produk BUMDes, sampai sekarang penggunaannya belum maksimal, sebab banyak masyarakat Desa Sugihwaras belum mengetahui adanya aplikasi tersebut, ketertarikannya hanya $40 \%$ saja. Hal ini tentu saja jauh dari rendah serta kurangnya informasi tentang aplikasi ini membuat kurang optimalnya fungsi $E$-Bes sebagai media pelayanan dan pengembangan masyarakat Desa Sugihwaras. Hal ini menjadi kelemahan dari pemasaran online yang dilakukan oleh BUMDes Sukses Bersama. Pada masa saat ini, masyarakat cenderung lebih belanja secara online dibandingkan harus datang ke tempat. Masyarakat digital merupakan karakter konsumen yang lahir dan dibentuk oleh peralihan gaya hidup 
belanja offline menjadi belanja online (Yaqub, 2020).

Persaingan antar sesama antar produk menjadi tantangan sekaligus ancaman bagi produk-produk BUMDes Sukses Bersama. Inovasi produk harus terus ditingkatkan untuk meminimalisir ancaman tersebut. Kepercayaan pelanggan juga harus dijaga dengan meningkatkan sistem penyaringan yang lebih baik agar tidak ada indikasi penipuan yang dilakukan pada penjual maupun pembeli (konsumen).

\section{Personal Selling melalui WhatsApp Marketing}

Bentuk pemasaran ini memanfaatkan fitur WhatsApp Story untuk menyebarkan informasi produk kepada konsumen. Kegiatan ini biasanya dilakukan oleh petugas atau pengurus BUMDes Sukses Bersama untuk menawarkan produk kepada teman di aplikasi WhatsApp. Strategi pemasaran online menggunakan cara ini memiliki kelebihan dan kekurangannya tersendiri, misalnya: a. Kelebihan: Cara ini dinilai cukup ampuh dan popular dalam menarik konsumen untuk membeli, karena mempunyai kepercayaan dan kedekatan kepada sumber informasi, dan Memberikan pelayanan secara personal dan akrab menjadi service marketing yang digunakan dalam bentuk pemasaran ini. b. Kekurangan: Keterbatasan bentuk pemasaran ini yaitu hanya dapat dilihat oleh kontak pribadi admin.

$$
\text { Strategi Pemasaran yang }
$$

dilaksanakan oleh BUMDes Sukses Bersama sudah dilakukan secara maksimal akan tetapi tingkat kepercayaan masyarakat lebih tinggi pada produk minimarket.

\footnotetext{
Dampak Strategi Pemasaran Produk Badan Usaha Milik Desa (BUMDesa) Sukses Bersama Desa Sugihwaras.
}

Badan Usaha Milik Desa (BUMDes) Sukses Bersama termasuk katagori BUMDes baru, akan tetapi perkembangannya termasuk cepat. Dibuktikan dengan keberadaan enam unit usahanya yang bergerak dibidang yang berbeda-beda dengan inovasi yang pesat pula. BUMDes milik Desa Sugihwaras turut serta mengembangkan pemasaran produknya melalui digital marketing. Strategi yang sedang popular saat ini yaitu market place. Dampak yang dirasakan dengan adanya strategi pemasaran berbasis online oleh BUMDes Sukses Bersama dalam upaya pengembangan Desa:

1. Dampak terhadap masyarakat Desa Sugihwaras. a. Dampak yang utama adalah melek teknologi, dimana sebelumnya kebanyakan masyarakat hanya bisa mengoprasikan teknologi handphone terbatas pada pesan singkat dan menelpon. Adanya aplikasi E-Bes menuntut masyarakat untuk melakukan pemasaran secara online jika ingin berjualan di aplikasi tersebut. b. Peningkatan jumlah penjualan produk, yang secara berkelanjutan akan meningkatkan kesejahteraan masyarakat desa dikarenakan BUMDes Sukses Bersama menjalin kerja sama untuk membuat suatu produk khas desa Sugihwaras.

2. Dampak terhadap BUMDesaSukses Bersama. Sejak dirilis pada 11 Agustus 2020 atau lebih tepatnya 7 bulan lalu sudah 100 lebih pengguna yang mendownload aplikasi E-Bes. Meskipun laporan penjualan BUMDes Sukses Bersama masih defisit, karena masih digunakan untuk biaya operasionalnya. Peningkatan penjualan sudah mulai terasa yakni sekitar 40\% warga Desa Sugihwaras sudah membeli produk BUMDes Sukses Bersama. 
Sesuai dengan hasil wawancara dengan Ibu Lailul Siti Romlah bahwa: "Untuk penjualan dan transaksi pembayaran pada aplikasi e-Bes mengalami peningkatan sejak tahun 2020, meskipun hanya 40\%. Peningkatan yang sangat signifikan terdapat pada transaksi pembayaran seperti POS FIN dan POS $M L O$ '. Pernyataan tersebut juga terbukti pada data sebagai berikut:

\section{Gambar 4. Jumlah Transaksi pembayaran POS FIN dan POS MLO BUMDes Sukses Bersama Oktober-Desember 2020}

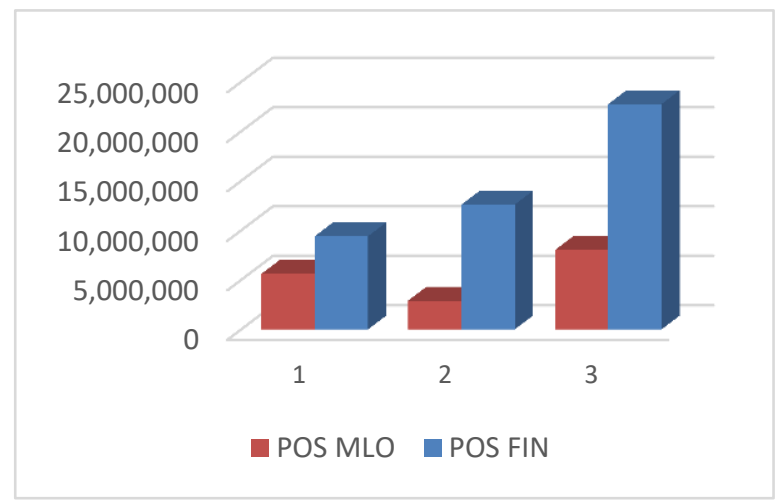

Sumber : Laporan Keuangan BUMDes Sukses Bersama (2020)

Dari data diatas menunjukkan bahwa perkembangan pada produk pembiayaan bulan Oktober sampai Desember tahun 2020 mengalami peningkatan dan penurunan. Seperti pada produk POS MLO mengalami penurunan dari bulan Oktober ke November yakni sebesar Rp. 2.700.000. Sedangkan pada bulan Desember mengalami peningkatan sebesar Rp. 5.100.000.

Inovasi-inovasi yang dilakukan Desa Sugihwaras dengan meningkatkan pelayanan kepada masyarakat desa melalui Digital Service, sekaligus menjadi ajang Branding desa. Tentu hal ini berdampak positif terhadap desa untuk terus meningkatkan mutu pelayanan dan perbaikan dalam upaya pengembangan desa.

\section{KESIMPULAN}

Berdasarkan dari penelitian yang dilakukan serta hasil yang telah dipaparkan oleh penulis pada bab sebelumnya, peneliti menarik kesimpulan yakni; Pertama, BUMDes Sukses Bersama Desa Sugihwaras sudah melakukan strategi pemasaran dan sosialisasi aplikasi belanja online bernama E-Bes sudah dilakukan secara maksimal akan tetapi tingkat kepercayaan masyarakat Desa Sugihwaras masih rendah karena lebih memilih produkproduk di minimarket. Kedua, dampak strategi pemasaran BUMDes Sukses Bersama Desa Sugihwaras diantaranya yakni : 1). Adanya aplikasi E-Bes menuntut masyarakat untuk melakukan pemasaran secara online jika ingin berjualan di aplikasi tersebut. 2). Peningkatan penjualan sudah mulai terasa yakni sekitar $40 \%$ warga Desa Sugihwaras sudah membeli produk BUMDesa Sukses Bersama.

\section{DAFTAR PUSTAKA}

Fadly, Hawangga Dhiyaul., \& Sutama. 2020. Membangun Pemasaran Online dan Digital Branding Ditengah Pandemi Covid-19. Jurnal Ecoment Global: Kajian Bisnis dan Manajemen, 5(2), p. 213-222.

Hastriyandi, H., \& Munandar, M. 2018. Penerapan Sistem Pemasaran Berbasis Online pada Produk 
Badan USAha Milik Desa (Bumdes) "Usaha Bersama "Desa Sebayan Kabupaten Sambas. Amaliah: Jurnal Pengabdian Kepada Masyarakat, 2(2), p. 189195.

Kotler, Philips \& Armstrong, Gary. 2011. Prinsip-Prinsip Pemasaran, Jilid 1 dan 2 (12th ed.). Erlangga. Jakarta.

Oktafia, R. 2017. Percepatan Pertumbuhan Usaha Mikro, Kecil Dan Menengah (Umkm) Melalui Perkuatan Lembaga Keuangan Mikro Syariah (Lkms) Di Jawa Timur. Proceedings of Annual Conference for Muslim Scholars, (Seri 1), 85-92. Retrieved from http://proceedings.kopertais4.or.id /index.php/ancoms/article/view/11.

Pamong. 2020. Penghargaan Bumdes Award 2020. Retrieved from Website Resmi Desa Sugihwaras: https://sugihwaras.desa.id/

Pradiani, T. 2017. Pengaruh Sistem Pemasaran Digital Marketing Terhadap Peningkatan Volume Penjualan Hasil Industri Rumahan. Jurnal Ilmiah Bisnis Dan Ekonomi Asia, 11(2), p. 46-53.

Primasatya, A. 2014. Penanganan Pembiayaan Mudharabah Bermasalah di Koperasi Syariah Kanindo Jatim (Studi di Koperasi Syariah Kanindo Jatim, Dau, Kabupaten Malang). Jurnal Ilmiah Fakultas Hukum Universitas Brawijaya, 3.

Siswanto, \& Tito. 2013. Optimalisasi Sosial Media Sebagai Media Pemasaran Usaha Kecil Menengah. Likuiditas, 2(1), p. 8086.

Sugiyono, P. D. 2018. Metode Penelitian Kuantitatif, Kualitatif, dan $R \& D$. Alfabeta. Bandung.
Sulistiyowati, I., Akbar, A., \& Latifah, F.N. 2021. Strategi Marketing 4.0 Pada UKM Danish Cake. In Seminar Nasional ADPI Mengabdi Untuk Negeri, 2(2), p. 300-303.

Wandanaya, A. B. 2012. Pengaruh Pemasaran Online Terhadap Keputusan Pembelian Produk. Creative Communication and Innovative Technology Journal, 5(2), p. 174-185.

Wibowo, D. H., Arifin, Z., \& Sunarti. 2015. Analisis Strategi Pemasaran Untuk Meningkatkan Daya Saing UMKM (Studi pada Batik Diajeng Solo). Jurnal Administrasi Bisnis, 29(1), 59-66.

Yaqub, M. 2020. Analisis Pengaruh Pemasaran Digital (Digital Marketing) Terhadap Brand Awareness pada E-Commerce. Jurnal Manajerial, 19(2), p. 198209. 